DOI: http://doi.org/10.21698/simi.2017.0036

\title{
MATERIAL COMPOSITION AND PROPERTIES OF RED MUD COMING FROM DOMESTIC ALUMINA PROCESSING PLANT
}

\author{
Georgiana Moise ${ }^{1}$, Petre Capota ${ }^{1}$, Lenuta Enache ${ }^{1}$, Eleonora Neagu ${ }^{1}$, Valentin Dragut ${ }^{1}$, \\ Daniel Mihaiescu ${ }^{1}$, Luminita Mara $^{1}$, Andreea Chirea ${ }^{1}$, Rodica Zavoianu ${ }^{2}$, Andrei Sarbu ${ }^{3}$ \\ ${ }^{1}$ National Research and Development Institute for Nonferrous and Rare Metals-IMNR, 102 \\ Biruintei Blvd, 0771145, Pantelimon, Romania, moise_geo_alexa@yahoo.com \\ ${ }^{2}$ University Bucharest, 36-46 Mihail Kogalniceanu Blvd, district 5, Bucharest, 0501107, \\ Romania, rodica.zavoianu@g.unibuc.ro \\ ${ }^{3}$ National Research and Development Institute for Chemistry and Petrochemistry - ICECHIM, \\ 202 Spl. Independentei, district 6, Bucharest, 06021, Romania, andr.sarbu@ gmail.com
}

\begin{abstract}
Red Mud from domestic alumina plant contains high excess alkaline components and traces of many toxic heavy metals. The results showed that Red Mud contains as main components hematite, goethite, residual aluminium oxide-hydroxides, desilication products (DSP), $\mathrm{TiO}_{2}$ and does not contain radioactive elements such as Uranium (U), Thorium (Th). U and Th in Red Mud are less than the average concentration values of Uranium (4ppm) and Thorium (12 ppm) in the earth's crust. Physical structural composition of domestic Red mud can be classified by an equilateral triangle iron oxide/hydroxide-sandy components-clays $\quad(23.2 \div 53.7 \%$ iron oxide/hydroxide; $34.1 \div 63.8 \%$ sandy components; $7.3 \div 34.1 \%$ clays $)$. Chemical composition of red mud is, by weight $\left(\%\right.$ w/w): $\mathrm{Fe}_{2} \mathrm{O}_{3} \mathrm{Tot}$ in the range 31.02 to $47.04 ; \mathrm{Na} 2 \mathrm{O}: 2.45 \div 5.39$; $\mathrm{CaO}$ : $3.01 \div 20.86 ; \quad \mathrm{K}_{2} \mathrm{O}: 0.02 \div 0.07 ; \mathrm{MgO}: 0.05 \div 0.73 ; \mathrm{Al}_{2} \mathrm{O}_{3}: 10.97 \div 22.78 ; \mathrm{SiO}_{2}$ : $1.09 \div 8.28 ; \mathrm{TiO}_{2}: 2.59 \div 5.76$; Loss of Ignition (LOI): $13.03 \div 38.75$. Red Mud also contains traces of some heavy metals and valuable metals (Cr, Mn, Zn, V, Ga, Gd, $\mathrm{Sc}$, etc.) and has the $\mathrm{pH}$ in the range $13.0 \div 11.9$ (when it is fresh) and $9 \div 10$ (when it is aged) respectively. The search results are an important basis to select the proper treatment and recovery this waste as secondary resources for ceramic materials production (ceramic foams).
\end{abstract}

Keywords: alumina plant, chemical analysis, material properties, red mud, wastes

\section{Introduction}

The red mud is the solid waste generated in the Bayer process alumina production $\left(\mathrm{Al}_{2} \mathrm{O}_{3}\right)$ from high bauxite grade ore, which has fine, micronized to colloidal texture and a chemical composition that varies due to the many types of bauxite processed over the time in Romania. The red mud contains mainly elements such as $\mathrm{Fe}, \mathrm{Al}, \mathrm{Si}$, $\mathrm{Ti}, \mathrm{Na}, \mathrm{Ca}$, traces components ( $\mathrm{V}, \mathrm{Ga}, \mathrm{Sc}, \mathrm{Mg}, \mathrm{Ba}, \mathrm{K}, \mathrm{Cu}, \mathrm{Pb}, \mathrm{Zn}, \mathrm{Cr}, \mathrm{Ce}, \mathrm{Gd}$ etc.) and has an excessively alkaline $\mathrm{pH}$. The high alkalinity level is due to the residual non-recoverable soda content; however it is acceptable for storage as non-hazardous waste (01 03 09), (Council Directive 91/689/EEC 1991). The US Environmental Protection Agency has rated red mud as a residue based on 4 risk characteristics: corrosively, reactivity, ignition capacity and extraction procedure toxicity but does not classify it as hazardous waste. However, large quantities generated globally at world level (between 0.8 and $2.0 \mathrm{Mt} / \mathrm{Mt} \mathrm{Al}_{2} \mathrm{O}_{3}$ ) could be a problem for the environment due to deposits and possible leaching under severe environmental 


\section{INTERNATIONAL SYMPOSIUM "THE ENVIRONMENT AND THE INDUSTRY", SIMI 2017, PROCEEDINGS BOOK}

conditions. At the same time, red mud pits can lead to impacts and risk perceived by the population in the areas surrounding these deposits by: landscape changes and visual discomfort, air pollution, surface water pollution, soil fertility changes and biocenosis composition on the land of adjacent landfills. Removal from the natural or economic circuit of land for red mud deposits is a process that can be considered temporary but which, in terms of the concept of "sustainable development", extends over at least two generations if the planning periods are summed up (1-3 years), exploitation period (about 15-30 years), ecological recovery and post-monitoring (1520 years). In terms of biodiversity, such a deposit means removing about 30-300 species / ha from the affected area, without considering the microbiological population of the soil. In addition, the biocenosis in the vicinity of the landfill are changing in the sense that vegetal associations become dominate by the ruderal species specific to the polluted areas, and some mammals, birds or insects leave the area. These features require precautionary storage and intense concerns for finding alternative solutions (a pre-treatment to reduce the level of alkalinity might be beneficial) and recovery (for example, as a secondary resource for production of building materials, special cements, adsorbents and catalysts for wastewater treatment, recovery of useful elements, and more recently the obtaining of ceramic oxide materials), (Çengeloğlu 2003; Paramguru 2005; Sglavo 2000; Yalcin 2000; Patent RO131328 (A2) 2016). The composition and properties of Red Mud in the world were presented by many researchers in their publications (Snars 2009). The results from this work showed that: Red Mud generated from domestic alumina plants contains a high content of oxides, such as: $\mathrm{Fe}_{2} \mathrm{O}_{3}, \mathrm{Al}_{2} \mathrm{O}_{3}, \mathrm{SiO}_{2}, \mathrm{TiO}_{2}, \mathrm{Na}_{2} \mathrm{O}, \mathrm{CaO}$, $\mathrm{K}_{2} \mathrm{O}, \mathrm{MgO}$, and sometimes a high concentration of valuable metal elements ( $\mathrm{V}, \mathrm{Ga}$, $\mathrm{Sc}, \mathrm{Gd}$, etc.) and does not contain radioactive elements such as $\mathrm{U}, \mathrm{Th}$, are less than the average concentration values of Uranium (4 ppm) and Thorium (12 ppm) in the earth's crust (Galateanu 1976; Hodgman 1960). The physical-structural composition of the domestic Red Mud is based on three classes of components: ironoxide/hydroxides-sandy components-clays. However, due to the bauxite origin and the technology utilized by the alumina processing plant, the composition and properties of Red Mud are very different. Currently, the alumina processing plant, from Romania, is a big and modern plant with a capacity 600,000 Mt of alumina annually (Vitmeco Alum 2017). The Romanian processing plant uses bauxite from the Sierra-Leone mine and other types of bauxite and Bayer technology for alumina production. A second alumina processing plant, which mainly used boehmitediaspore and boehmite-gibbsite bauxite ore, was closed several years ago, but there are still red mud deposits in its vicinity. Investigation of the composition and properties of Red Mud from domestic alumina processing plant in order to turn its use towards the obtaining of ceramic oxide materials (foams) is a main objective of the project "WATOPREM" PN-II-PT-PCCA-2013-4-177, Ctr. 78/2014.

\section{Materials and Methods}

Fresh Red Mud (RM2, RM7, RM8, RM9 red mud samples) were collected from red mud deposits located in vicinity of alumina processing plant from east of Romania, in April, 2015;

Older Red Mud (up to 1 year aged), RM10, RM11, RM12, RM13, RM14 red mud samples, were collected from a red mud deposit near the closed alumina processing plant from west of Romania, in February 2013. 


\section{INTERNATIONAL SYMPOSIUM "THE ENVIRONMENT AND THE INDUSTRY", SIMI 2017, PROCEEDINGS BOOK}

\section{Determination of basic physical and chemical characteristics of Red Mud}

Physical texture of Red Mud was determined using dry sieving-classified particles method according to the methods SR EN 244971994; SR EN 12192-1 2003.

Red mud samples dissolved by hot acid $\mathrm{HCl} \mathrm{1:1,} \mathrm{norm} \mathrm{up} 250 \mathrm{~mL}$, or through dissolution in $\mathrm{HNO}_{3}+\mathrm{HCl}$ acids while the solid residues were digested by fusing $\mathrm{Na}_{2} \mathrm{CO}_{3}$ and $\mathrm{K}_{2} \mathrm{CO}_{3}$ in a platinum dish at $1,000^{\circ} \mathrm{C}$. The solutions were used to determine the percent concentration $(\% \mathrm{w} / \mathrm{w})$ of the oxides and heavy metals.

$\mathrm{Fe}_{2} \mathrm{O}_{3}, \mathrm{Al}_{2} \mathrm{O}_{3}, \mathrm{SiO}_{2}, \mathrm{TiO}_{2}, \mathrm{MgO}$, trace elements: $\mathrm{Cu}, \mathrm{Cr}, \mathrm{Ni}, \mathrm{Zn}, \mathrm{Zr}, \mathrm{Ba}, \mathrm{Ce}, \mathrm{Gd}, \mathrm{Sc}$, U, Th were determined by the spectrometric methods SR EN 14242 2005; ASTM E1479 2016, using an ICP-OES AGILENT 725 equipment;

$\mathrm{Na}_{2} \mathrm{O}, \mathrm{CaO}, \mathrm{K}_{2} \mathrm{O}$, trace elements $\mathrm{Ga}, \mathrm{Cd}$ and $\mathrm{Pb}$ were analysed by atomic absorption spectrometry using AAS ZEEnit 700 Analytic Jena AG firm, Germany equipment according to STAS 3223/2- 1980; STAS 3223/1 1992; STAS 1269/17 1982; STAS 1269/7 1983; STAS 1269/3 1987, IEC 61010-2-061, 2015.

Loss on Ignition (LOI) was determined by chemical analysis method according to SR 9934-2 1998 standard.

$\mathrm{pH}$ of Red Mud sludge (in water and saline suspensions - mass/volume) was determined according to the methods SR 7184-13 2001; SR EN 60746-1 2004; SR EN 60746-2 2004.

\section{Mineral composition analysis}

The mineral composition of red mud has been determined by X-rays diffraction method Bragg-Bretano $\Theta-2 * \Theta$ on BRUKER diffractometer XRD D8 Advance with $\mathrm{CuK} \alpha$ radiation and software DIFFRAC ${ }^{\text {PLUS }}$ XRD Commender - BRUKER AXS, EVA12, 2006. X-ray diffraction angle varied from $4^{0}$ to $74^{0}, \mathrm{U}=40 \mathrm{kV}, \mathrm{I}=40 \mathrm{~mA}$.

\section{Determination of radioactive level}

The radioactive level have been analysed by dose rate measuring method covering the range of the environmental back-ground up to the dose rate range of $200 \mu \mathrm{Sv} \cdot \mathrm{h}^{-1}$ $50 \mu \mathrm{Sv}^{\cdot} \cdot \mathrm{h}^{-1}$ on SCINTO dose rate meter instrument with Scintillation Detector $(\mathrm{NaI})$ $1.5 \times 1$ " for the measurement of Gamma-radiation and X-rays, Germany according to EN 55011 (Class B); EN 61326-A1; EN 61326-1(Class B). By means of the scintillation detector it is possible to perform measurements in the energy range from approx. $25 \mathrm{keV}$ up.

\section{Results and Discussion}

\section{Physical texture of Red Mud}

Analysing results of physical texture of Red Mud was shown in Table 1, Box plots from Fig. 1 and Fig. 2.

The results presented in Table 1 and Fig. 1 and 2 showed that, the physical texture of Red Mud classified by an equilateral triangle iron oxide/hydroxide-sandy components-clays are: $23,2 \div 53,7 \%$ iron oxide/hydroxide; $34,1 \div 63,8 \%$ sandy components and $7,3 \div 34,1 \%$ clays for fresh and aged Red Mud. 
Table 1. Physical texture of red mud

\begin{tabular}{|c|c|c|c|c|c|c|c|c|}
\hline \multirow[b]{2}{*}{$\begin{array}{c}\begin{array}{c}\text { Mean } \\
\text { aperture } \\
\text { of } \\
\text { passing/ } \\
\text { retaining } \\
\text { sieves } \\
\mathbf{x}_{\mathbf{i}},(\mathbf{m m})\end{array} \\
\end{array}$} & \multicolumn{4}{|c|}{ Fresh red mud } & \multicolumn{4}{|c|}{ Aged red mud } \\
\hline & $\begin{array}{c}\text { Cumulate } \\
\text { distribution } \\
\mathbf{Q}_{3}\left(\mathbf{x}_{\mathbf{i}}\right)\end{array}$ & $\begin{array}{c}\text { Density } \\
\text { distribution } \\
\mathbf{q}_{3}\left(\mathbf{x}_{\mathbf{i}}\right), \\
{[\mathbf{1} / \mathbf{m m}]}\end{array}$ & $\begin{array}{c}\text { Cumulate } \\
\text { weight } \\
(\%) \\
\text { passing }\end{array}$ & $\begin{array}{c}\text { Average } \\
\text { particle } \\
\text { size } \\
\text { P80 } \\
(\mathbf{m m})\end{array}$ & $\begin{array}{c}\text { Cumulate } \\
\text { distribution } \\
\mathbf{Q}_{3}\left(\mathbf{x}_{\mathbf{i}}\right)\end{array}$ & $\begin{array}{c}\text { Density } \\
\text { distribution } \\
\mathbf{q}_{3}\left(\mathbf{x}_{\mathbf{i}}\right), \\
{[\mathbf{1} / \mathbf{m m}]}\end{array}$ & $\begin{array}{c}\text { Cumulate } \\
\text { weight } \\
(\%) \\
\text { passing }\end{array}$ & $\begin{array}{c}\text { Average } \\
\text { particle } \\
\text { size } \\
\text { P80 } \\
(\mathbf{m m})\end{array}$ \\
\hline 0.2 & 0.0238 & 0.0031 & 97.76 & \multirow{4}{*}{0.038} & 0.1161 & 0.0155 & 93.26 & \multirow{4}{*}{0.049} \\
\hline 0.125 & 0.0347 & 0.0056 & 93.80 & & 0.1158 & 0.0187 & 85.64 & \\
\hline 0.063 & 0.6316 & 0.2746 & 54.43 & & 0.7478 & 0.3251 & 25.46 & \\
\hline 0.040 & 0.3099 & 0.0775 & 39.99 & & 0.0201 & 0.0050 & 10.03 & \\
\hline
\end{tabular}

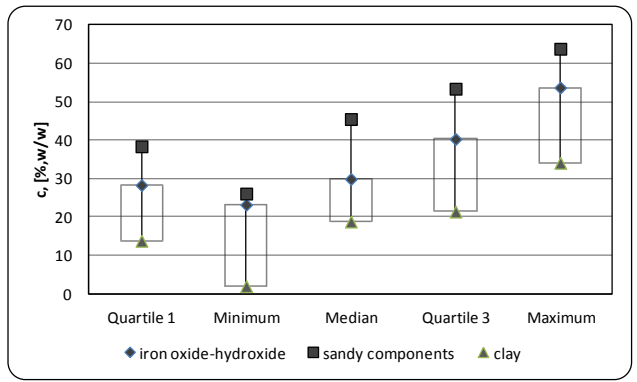

Figure 1. Box plots, physical texture of Red Mud

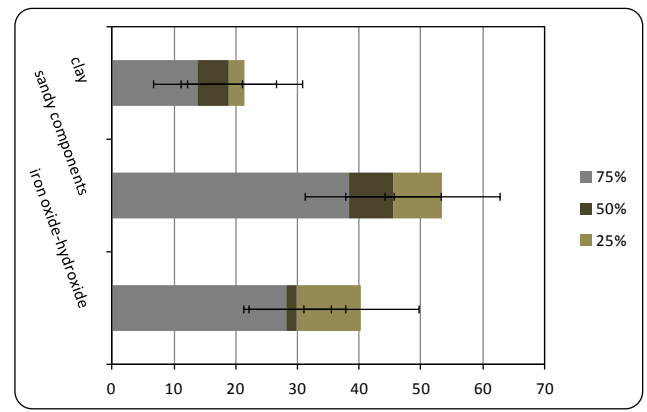

Figure 2. Box plots, physical texture of Red Mud

Particle size distribution in Red Mud showed a fine physical texture of solid sludge: $>93.80 \%$ particles smaller than $0.125 \mathrm{~mm}$ size in fresh Red Mud and respectively, higher 85.64 percent of particles with lower size of $0.125 \mathrm{~mm}$ in aged Red Mud.

The chemical composition of the red mud samples expressed as distribution of oxides The chemical composition of the fresh and aged red mud samples expressed as distribution of oxides is presented in Table 2. In high-grade bauxite ore, iron is commonly found as minerals such as: Hematite $\left(\alpha-\mathrm{Fe}_{2} \mathrm{O}_{3}\right)$, Goethite $(\alpha-\mathrm{FeOOH})$, Magnetite ( $\left.\mathrm{FeO} . \mathrm{Fe}_{2} \mathrm{O}_{3}\right)$, clay minerals, (Patterson 1986; Borra 2016). 


\section{INTERNATIONAL SYMPOSIUM "THE ENVIRONMENT AND THE INDUSTRY", SIMI 2017, PROCEEDINGS BOOK}

Table 2. Concentration of oxides in Red Mud, fresh and aged samples, (\%w/w)

\begin{tabular}{|c|c|c|c|c|c|c|c|c|c|c|}
\hline \multicolumn{2}{|c|}{ Sample } & $\begin{array}{c}\mathrm{Fe}_{2} \mathrm{O} \\
3\end{array}$ & $\begin{array}{c}\mathrm{Al}_{2} \mathrm{O} \\
3\end{array}$ & $\begin{array}{c}\mathrm{SiO} \\
2\end{array}$ & $\begin{array}{c}\mathrm{TiO} \\
2\end{array}$ & $\begin{array}{c}\mathrm{Na}_{2} \\
\mathrm{O}\end{array}$ & $\begin{array}{c}\mathrm{K}_{2} \\
\mathrm{O}\end{array}$ & $\mathrm{CaO}$ & $\begin{array}{c}\mathrm{Mg} \\
\mathrm{O}\end{array}$ & $\begin{array}{c}\text { L.O.I } \\
.\end{array}$ \\
\hline \multirow{4}{*}{$\begin{array}{c}\text { Fres } \\
\mathrm{h} \\
\text { mud }\end{array}$} & RM2 & 37.97 & 16.79 & 5.56 & 3.56 & 2.97 & $\begin{array}{c}0.0 \\
6\end{array}$ & 4.15 & 0.10 & 28.75 \\
\hline & RM7 & 47.04 & 14.92 & 7.48 & 3.07 & 4.08 & $\begin{array}{c}0.0 \\
3\end{array}$ & 3.36 & 0.05 & 17.67 \\
\hline & RM8 & 42.89 & 18.19 & 8.28 & 2.77 & 5.39 & $\begin{array}{c}0.0 \\
2\end{array}$ & 3.30 & 0.05 & 17.47 \\
\hline & RM9 & 44.46 & 19.83 & 7.51 & 3.27 & 4.81 & $\begin{array}{c}0.0 \\
2\end{array}$ & 3.01 & 0.07 & 16.46 \\
\hline \multirow{5}{*}{$\begin{array}{c}\text { Age } \\
\text { d } \\
\text { mud }\end{array}$} & $\begin{array}{c}\text { RM1 } \\
0\end{array}$ & 43.18 & 11.50 & 2.34 & 5.76 & 2.45 & $\begin{array}{c}0.0 \\
2\end{array}$ & $\begin{array}{c}16.9 \\
4\end{array}$ & 0.73 & 18.30 \\
\hline & $\begin{array}{c}\text { RM1 } \\
1\end{array}$ & 31.02 & 11.26 & 0.84 & 2.80 & 2.84 & $\begin{array}{c}0.0 \\
4\end{array}$ & $\begin{array}{c}23.1 \\
0\end{array}$ & 0.41 & 26.52 \\
\hline & $\begin{array}{c}\text { RM1 } \\
2\end{array}$ & 35.31 & 10.97 & 1.09 & 2.85 & 2.98 & $\begin{array}{c}0.0 \\
4\end{array}$ & $\begin{array}{c}20.8 \\
6\end{array}$ & 0.38 & 24.98 \\
\hline & $\begin{array}{c}\text { RM1 } \\
3\end{array}$ & 35.03 & 22.78 & 1.56 & 5.04 & 4.93 & $\begin{array}{c}0.0 \\
2\end{array}$ & 9.97 & 0.35 & 17.51 \\
\hline & $\begin{array}{c}\text { RM1 } \\
4\end{array}$ & 33.60 & 21.57 & 2.01 & 2.59 & 4.87 & $\begin{array}{c}0.0 \\
7\end{array}$ & 5.35 & 0.28 & 26.76 \\
\hline
\end{tabular}

The results in Table 2 showed that in fresh Red Mud the iron content as $\mathrm{Fe}_{2} \mathrm{O}_{3}$ was $37.97 \div 44.46 \%$ which is 1.2 times higher than in the aged Red Mud. A similar trend is noticed for $\mathrm{Al}_{2} \mathrm{O}_{3}$ content, which in fresh red mud was in average $17.43 \%$, slightly higher than in aged red mud. Silicon, which is the second element as percentage after oxygen in the earth crust, is commonly found in soil as Quartz $\left(\mathrm{SiO}_{2}\right)$. In Red Mud, Silicon can be found also as Quartz and clay minerals (desillication products - DSP, Cancrinite $\quad 3 \mathrm{Na}_{2} \mathrm{O} \cdot 3 \mathrm{Al}_{2} \mathrm{O}_{3} \cdot 5 \mathrm{SiO}_{2} \cdot 5 \mathrm{H}_{2} \mathrm{O} \cdot \mathrm{Na}_{2} \mathrm{CO}_{3}, \quad$ Cancrisillite/Sodalite $\mathrm{Na}_{4} \mathrm{Al}_{3} \mathrm{Si}_{3} \mathrm{O}_{12} \cdot \mathrm{Cl}$; Katoite $\left.\left.\mathrm{Ca}_{3} \mathrm{Al}_{2}\left(\mathrm{SiO}_{4}\right)(\mathrm{OH})_{8}\right)\right)$. The results in Table 2 showed that $\mathrm{SiO}_{2}$ concentration in fresh red mud was in average $7.21 \%$, higher than in aged red mud $(0.84 \div 2.34 \%)$. Meanwhile the concentration of $\mathrm{TiO}_{2}$ concentration was higher in the aged red mud (average concentration 3.81\%), than in fresh red mud (average concentration $3.17 \%$ ). These differences in the chemical compositions are related to the bauxite ore sources for the two types of technologies and corresponding emerging deposits. Analysing the results in Table 2 showed that the residual non-recoverable soda content $\mathrm{Na}_{2} \mathrm{O}$ in fresh red mud is comparable to the values obtained at the analysis of the aged red mud. Potassium element, both present in fresh and aged Red Mud $(0.02 \div 0.07 \%)$ was lower than K content in the Earth's crust. The estimated average Potassium $(\mathrm{K})$ concentration in the Earth's crust is in the order of $1.84 \%$ to $2.3 \%$, (O'Brien 2008). Most of this $\mathrm{K}$ is bound in primary minerals or is present in the secondary clay minerals, which largely make up the clay fraction of the soil of particle size less than 2 micrometre (O'Brien 2008). Exchangeable $\mathrm{K}^{+}$is electrostatically bound to the surface of clay minerals and humus substances present in Red Mud. $\mathrm{CaO}$ concentration in fresh red mud was $3.1 \div 4.15 \%$ which was much lower than the $\mathrm{CaO}$ content in the aged red mud (which has suffered during depositing a subsequent treatment with lime). The same behaviour was noticed for $\mathrm{MgO}$ content in fresh mud which was $0.5 \div 1 \%$ lower than $\mathrm{MgO}$ content in aged red mud $(0.28 \div 0.73 \%)$. 


\section{INTERNATIONAL SYMPOSIUM "THE ENVIRONMENT AND THE INDUSTRY", SIMI 2017, PROCEEDINGS BOOK}

The distribution of trace elements (heavy metals and rare elements) in indigenous Red Mud

The results of the trace analysis for heavy metals and rare elements concentration in fresh and aged Red Mud are given in Table 3.

Table 3. Concentration of heavy and rare metals in Red Mud from domestic alumina processing plants, (ppm)

\begin{tabular}{|c|c|c|c|c|c|c|c|c|c|}
\hline \multirow[b]{2}{*}{$\begin{array}{c}\text { Meta } \\
1\end{array}$} & \multicolumn{4}{|c|}{ Fresh Red Mud } & \multicolumn{5}{|c|}{ Aged Red Mud } \\
\hline & RM2 & RM7 & RM8 & RM9 & $\begin{array}{c}\text { RM1 } \\
\text { 0 }\end{array}$ & $\begin{array}{c}\text { RM1 } \\
1\end{array}$ & $\begin{array}{c}\text { RM1 } \\
2\end{array}$ & $\begin{array}{c}\text { RM1 } \\
\mathbf{3}\end{array}$ & $\begin{array}{c}\text { RM1 } \\
4\end{array}$ \\
\hline $\mathrm{V}$ & 28 & 150 & 22 & 240 & 300 & 23 & 200 & 190 & 300 \\
\hline $\mathrm{Ga}$ & 50 & 61 & 61 & 67 & 56 & 50 & 46 & 64 & 77 \\
\hline $\mathrm{Cd}$ & 15 & 22 & 17 & 15 & 43 & 31 & 32 & 35 & 33 \\
\hline $\mathrm{Cu}$ & 34 & 90 & 100 & 94 & 96 & 81 & 86 & 82 & 100 \\
\hline $\mathrm{Cr}$ & 73 & 665 & 845 & 912 & 900 & 2,400 & 3,400 & 1,000 & 700 \\
\hline $\mathrm{Ni}$ & 45 & 90 & 85 & 88 & 28 & 350 & 33 & 46 & 50 \\
\hline $\mathrm{Pb}$ & 56 & 20 & 15 & 21 & 270 & 7,900 & 1,240 & 180 & 70 \\
\hline $\mathrm{Zn}$ & 32 & 37 & 34 & 65 & 96 & 660 & 1,000 & 59 & 62 \\
\hline $\mathrm{Ba}$ & 10 & 13 & 20 & 110 & 260 & 1,600 & 1,500 & 480 & 330 \\
\hline $\mathrm{Zr}$ & 40 & 18 & 120 & 130 & 1,100 & 570 & 590 & 250 & 750 \\
\hline $\mathrm{Ce}$ & 10 & 10 & 13 & 21 & 628 & 282 & 204 & 250 & 520 \\
\hline $\mathrm{Gd}$ & 15 & 19 & 25 & 32 & 65 & 44 & 43 & 53 & 32 \\
\hline $\mathrm{Sc}$ & 20 & 38 & 43 & 38 & 120 & 62 & 64 & 70 & 52 \\
\hline $\mathrm{U}$ & $<2.0$ & $<2.0$ & $<2.0$ & $<2.0$ & $<2.0$ & $<2.0$ & $<2.0$ & $<2.0$ & $<2.0$ \\
\hline Th & $\begin{array}{c}<10 . \\
0\end{array}$ & $\begin{array}{c}<10 . \\
0\end{array}$ & $\begin{array}{c}<10 . \\
0\end{array}$ & $\begin{array}{c}<10 . \\
0\end{array}$ & $<10.0$ & $<10.0$ & $<10.0$ & $<10.0$ & $<10.0$ \\
\hline
\end{tabular}

According to the results in Table 3, both fresh and aged Red Mud contain trace concentrations of many heavy metals and rare elements (V, Ga, Cd, Cu, Cr, Ni, Gd, Sc). Heavy metals may become hazardous for environment (soil, water, air) by successive accumulation. The content of Uranium and Thorium in the investigated Red Mud was lower than the average content of Uranium (4 ppm) and Thorium (12 ppm) in the Earth's crust (Table 3). From the broad composition of red mud, some of the heavy metals and rare elements such as: Fe, Ti, V, Ga, Sc, and Gd can be extracted as valuable economic resources.

pH of Red Mud sludge

The $\mathrm{pH}$ values of the investigated Red Mud samples in aqueous suspension (w/w= liquid: solid ratio $=10: 1$ ) are displayed in Table 4 .

Table 4. $\mathrm{pH}$ value of Red Mud sludge

\begin{tabular}{|c|c|c|c|c|c|c|c|c|c|c|c|}
\hline No. & $\begin{array}{c}\text { fresh } \\
\text { Red } \\
\text { mud }\end{array}$ & $\mathrm{pH}_{\mathrm{H} 2 \mathrm{O}}$ & $\mathbf{p H}_{\mathrm{KCl}}$ & No. & $\begin{array}{l}\text { aged } \\
\text { Red } \\
\text { Mud }\end{array}$ & $\mathrm{pH}_{\mathrm{H} 2 \mathrm{O}}$ & $\mathbf{p H}_{\mathrm{KCl}}$ & No. & $\begin{array}{l}\text { aged } \\
\text { Red } \\
\text { Mud }\end{array}$ & $\mathrm{pH}_{\mathrm{H} 2 \mathrm{O}}$ & $\mathbf{p H}_{\mathrm{KCl}}$ \\
\hline 1 & RM2 & 11.30 & 10.87 & 5 & RM10 & 9.10 & 8.74 & 9 & RM14 & 9.96 & 9.97 \\
\hline 2 & RM7 & 11.60 & 10.97 & 6 & RM11 & 9.35 & 9.13 & - & - & - & \\
\hline 3 & RM8 & 11.90 & 10.20 & 7 & RM12 & 9.48 & 9.02 & - & - & - & \\
\hline 4 & RM9 & 11.98 & 10.25 & 8 & RM13 & 9.92 & 10.18 & - & - & - & \\
\hline
\end{tabular}




\section{INTERNATIONAL SYMPOSIUM "THE ENVIRONMENT AND THE INDUSTRY", SIMI 2017, PROCEEDINGS BOOK}

The results in Table 4 showed that the $\mathrm{pH}$ of fresh Red Mud was $1.22 \%$ higher than for the aged Red Mud, and it decreased with the increase of the storage time. Na dominated among the soluble cations, but the concentration of soluble $\mathrm{Na}$, decreased with increasing duration of storage time as a result of leaching (natural weathering). Ca was the predominant exchangeable cation in fresh Red Mud but the concentration of exchangeable Ca markedly decreased in aged Red Mud, which was dominated by exchangeable $\mathrm{Na}$. This fact suggests that in the fresh red mud a higher amount of $\mathrm{Ca}$ is found as soluble species, while in the aged red mud which has also suffered a subsequent treatment with lime $\mathrm{Ca}$ was mainly converted to non-soluble species. Therefore, cation exchange capacity also decreased with increasing period of storage time. It could also be assumed that this fact could be due to a decrease in $\mathrm{pH}$ causing a reduction in negatively charged sites on the red mud particle. A high $\mathrm{pH}$ of Red Mud suspension may have a strong environmental impact on soil and surface waters.

\section{Mineral composition of Red Mud}

Mineral composition of research Red Mud (fresh and aged mud) generated from domestic alumina processing plant has been determinate by X-ray diffraction method is showed in Table 5.

Table 5. Mineral composition of Red Mud determined by X-ray diffraction method

\begin{tabular}{|c|c|c|c|c|c|c|c|c|c|c|c|c|c|c|c|c|}
\hline \multicolumn{2}{|c|}{$\begin{array}{c}\text { Compou } \\
\text { nd }\end{array}$} & 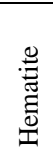 & 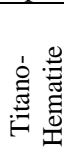 & $\begin{array}{l}\stackrel{0}{\Xi} \\
\stackrel{0}{0} \\
0 \\
0\end{array}$ & $\begin{array}{l}\frac{0}{0} \\
00 \\
0 \\
0\end{array}$ & 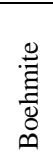 & 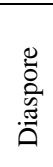 & $\frac{\mathscr{0}}{\frac{0}{\pi}}$ & 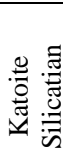 & & 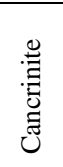 & 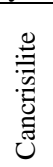 & 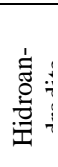 & $\stackrel{\stackrel{N}{*}}{\stackrel{\Xi}{\Xi}}$ & 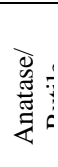 & $\begin{array}{l}\stackrel{g}{\Xi} \\
\stackrel{\Xi}{\Xi}\end{array}$ \\
\hline \multicolumn{2}{|c|}{ Formula } & 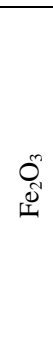 & 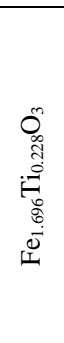 & 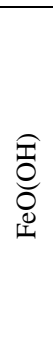 & 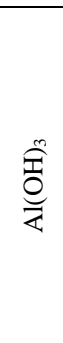 & $\frac{\widehat{O}}{0}$ & 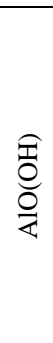 & 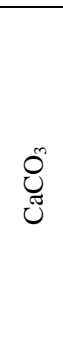 & 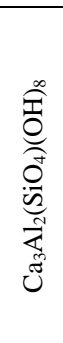 & 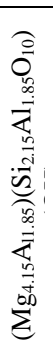 & 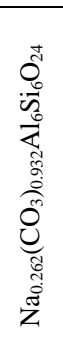 & 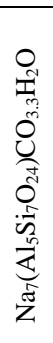 & 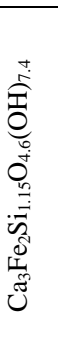 & $\stackrel{0}{\infty}$ & $\stackrel{0}{N}$ & 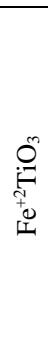 \\
\hline \multirow{4}{*}{ 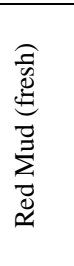 } & RM2 & 10. & - & 34. & 29. & - & - & 5.0 & - & - & 14. & - & 7. & - & 1. & - \\
\hline & RM7 & $\begin{array}{c}14 . \\
8\end{array}$ & - & $\begin{array}{c}25 . \\
5\end{array}$ & 8.0 & $\begin{array}{c}3 . \\
1\end{array}$ & - & 4.8 & 12.2 & - & - & $\begin{array}{l}9 . \\
2\end{array}$ & - & 7.3 & $\begin{array}{l}1 . \\
5\end{array}$ & $\begin{array}{c}13 . \\
7\end{array}$ \\
\hline & RM8 & 9.1 & - & $\begin{array}{c}17 . \\
6\end{array}$ & $\begin{array}{c}25 . \\
4\end{array}$ & $\begin{array}{l}1 . \\
9\end{array}$ & - & 7.5 & 7.0 & - & - & $\begin{array}{l}6 . \\
8\end{array}$ & - & $\begin{array}{c}17 . \\
5\end{array}$ & 1. & - \\
\hline & RM9 & $\begin{array}{c}12 . \\
1\end{array}$ & - & $\begin{array}{c}16 . \\
8\end{array}$ & $\begin{array}{c}35 . \\
0\end{array}$ & $\begin{array}{l}2 . \\
4\end{array}$ & - & $\begin{array}{c}13 . \\
1\end{array}$ & - & - & - & $\begin{array}{l}7 . \\
3\end{array}$ & - & 4.7 & $\begin{array}{l}1 . \\
5\end{array}$ & 7.1 \\
\hline \multirow{5}{*}{ 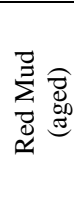 } & RM10 & - & $\begin{array}{c}46 . \\
8\end{array}$ & - & 5.5 & - & $\begin{array}{l}5 . \\
2\end{array}$ & $\begin{array}{c}23 . \\
4\end{array}$ & 7.0 & - & $\begin{array}{c}12 . \\
0\end{array}$ & - & - & - & - & - \\
\hline & RM1 & - & 26.5 & 1.8 & 5.5 & - & 8.2 & 39.2 & 5.2 & 3.2 & 10.4 & - & - & - & - & - \\
\hline & RM12 & - & 27.8 & 3.4 & 2.2 & - & 5.7 & 37.6 & 5.7 & 4.9 & 12.7 & - & - & - & - & - \\
\hline & $\mathrm{R}$ & - & 19.0 & 4.2 & 12.3 & 2.8 & 8.1 & 15.1 & 10.1 & 4.0 & 20.0 & - & - & - & 4.3 & - \\
\hline & RM14 & - & 10.0 & 19.9 & 20.4 & 2.2 & 4.8 & 17.2 & 5.9 & - & 9.6 & - & - & 7.2 & 2.8 & - \\
\hline
\end{tabular}




\section{INTERNATIONAL SYMPOSIUM "THE ENVIRONMENT AND THE INDUSTRY", SIMI 2017, PROCEEDINGS BOOK}

According to Table 5, almost all the components in the investigated Red Mud component are found as microcrystal states which can be determined by X-ray diffraction patterns. The degree of crystallization of the red mud increased with increasing duration of storage. Main mineral components determined by $\mathrm{X}$-ray diffraction patterns were Hematite $\left(\alpha-\mathrm{Fe}_{2} \mathrm{O}_{3}\right)$, Goethite $[\alpha-\mathrm{FeO}(\mathrm{OH})]$, Gibbsite $[\gamma-$ $\left.\mathrm{Al}(\mathrm{OH})_{3}\right]$, Boehmite $[\gamma-\mathrm{AlO}(\mathrm{OH})]$, Calcite $\left(\mathrm{CaCO}_{3}\right)$, Quartz $\left(\mathrm{SiO}_{2}\right)$ and new synthetic minerals with chemical formula Cancrinite $\left(\mathrm{Na} 0.262\left(\mathrm{CO}_{3}\right)_{0.932} \mathrm{Al}_{6} \mathrm{Si}_{6} \mathrm{O}_{24}\right)$, Cancrisilite $\left(\mathrm{Na}_{7}\left(\mathrm{Al}_{5} \mathrm{Si}_{7} \mathrm{O}_{24}\right) \mathrm{CO}_{3.3} \mathrm{H}_{2} \mathrm{O}\right)$, Katoite Sillicatian $\left[\mathrm{Ca}_{3} \mathrm{Al}_{2}\left(\mathrm{SiO}_{4}\right)(\mathrm{OH})_{8}\right]$. Hematite can occur partially from the dehydration of the Goethite, as a phase called "protoHematite" in literature date, which has although the structure of the hematite but is deficient in iron and still retains hydroxyl groups $\left(\mathrm{Fe}_{2-\mathrm{x} / 3} \mathrm{O}_{3} \mathrm{H}_{\mathrm{x}}\right)$. Goethite has diffraction lines slightly offset to values of smaller interplanar spacing suggesting the formation of solid solutions with Diaspore, Goethite aluminian [(Fe, $\mathrm{AlO}(\mathrm{OH})]$. Boehmite $\mathrm{AlO}(\mathrm{OH})$, Gibbsite $\mathrm{Al}(\mathrm{OH})_{3}$, Calcite $\mathrm{CaCO}_{3}$ and Rutile/Anatase $\mathrm{TiO}_{2}$ do not appear to form solid solutions. Cancrinite with the ideal formula $\mathrm{Na}_{6} \mathrm{Ca}_{2} \mathrm{Al}_{6} \mathrm{Si}_{6} \mathrm{O}_{24}\left(\mathrm{CO}_{3}\right)_{2}$ knows the great variations due to possible substitutions:

$$
\begin{gathered}
\mathrm{CaCO}_{3} \leftrightarrow \mathrm{NaHCO}_{3}, \\
\mathrm{CaCO} \mathrm{Na}_{2} \mathrm{CO}_{3}+\text { vacancies, } \\
\mathrm{Ca}^{2+} \leftrightarrow \mathrm{Mg}^{2+}, \text { in a small proportion, } \\
\mathrm{Si}^{4+} \leftrightarrow \mathrm{Ti}^{4+}, \text { in a small proportion, } \\
\mathrm{Na}^{+} \leftrightarrow \mathrm{K}^{+}, \text {in a small proportion, } \\
\mathrm{Al}^{3+} \leftrightarrow \mathrm{Fe}^{3+}, \text { in a small proportion, }
\end{gathered}
$$

Cancrisilite with ideal formula $\mathrm{Na}_{7} \mathrm{Al}_{5} \mathrm{Si}_{7} \mathrm{O}_{24}\left(\mathrm{CO}_{3}\right) \cdot 3 \mathrm{H}_{2} \mathrm{O}$, has the same structure as Cancrinite and shows variations due to similar substitutions.

Amesite with the ideal composition $\left(\mathrm{Mg}_{2} \mathrm{Al}\right)\left(\mathrm{AlSiO}_{5}\right)(\mathrm{OH})_{4}$ belongs to the kaolinite group and also accepts a series of isomorphic substitutions:

$$
\begin{gathered}
M g^{2+} \leftrightarrow F e^{2+}, \text { in large proportions, } \\
M g^{2+} \leftrightarrow \mathrm{Ca}^{2+} \leftrightarrow \mathrm{Mn}^{2+}, \text { in small proportion, }
\end{gathered}
$$

\section{Measurements of radioactive level of Red Mud}

Table 6 shows the radioactive level of the investigated Red Mud samples generated from domestic alumina processing plants were determined by Gamma radiation measurement method. The resulting range of annual average effective absorbed doses in air and received by adults were estimated in according to United Nations Scientific Committee on the Effects of Atomic Radiation (UNSCEAR 2000).

According to the standard for residents, the limit of the total annual effective dose of gamma radiation is $1 \mathrm{mSv}$. Annual effective dose due to natural gamma fond, according to United Nations Scientific Committee on the Effects of Atomic Radiation to the General Assembly, is $0.48 \mathrm{mSv}$ (UNSCEAR 2000). The results in Table 6 showed that the effective dose of gamma radiation of the fresh and aged Red Mud from domestic alumina processing plants varied in a small range from $72 \mathrm{nSv} \cdot \mathrm{h}^{-1}$ to $79 \mathrm{nSv} \cdot \mathrm{h}^{-1}$ and, subsequently the annual effective dose of gamma radiation was estimated in the range $0.505-0.554 \mathrm{mSv}$, which is fairly close to the average effective annual dose due to gamma radiation natural fond $(0.48 \mathrm{mSv})$. 


\section{INTERNATIONAL SYMPOSIUM "THE ENVIRONMENT AND THE INDUSTRY", SIMI 2017, PROCEEDINGS BOOK}

Table 6. Effective gamma radiation dose of Red Mud samples, comparative values with natural fond

\begin{tabular}{|c|c|c|c|}
\hline 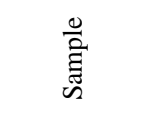 & 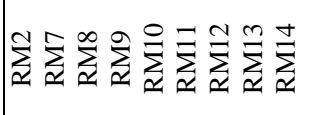 & 苞 & 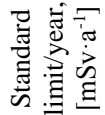 \\
\hline 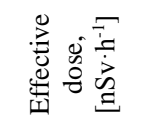 & 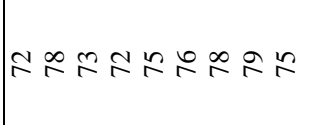 & $\curvearrowleft$ & ' \\
\hline 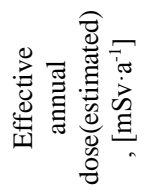 & 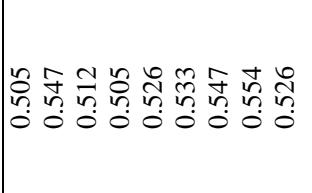 & $\begin{array}{l}\text { N } \\
\text { ñ } \\
0\end{array}$ & $\stackrel{0}{\vec{v}}$ \\
\hline
\end{tabular}

\section{Conclusions}

Considering the three main categories of compounds (iron oxides-hydroxides, sands and clays) generating the textural properties of the red mud generated from both Romanian alumina processing plants, it may be inferred that these materials could be utilized to generate ceramic foams.

However, due to the fact that these residues have a high free alkalinity, a pre-treatment process for lowering the Na soluble content level is imperiously necessary before their utilization in ceramic foams synthesis.

Taking into account that both types of red mud contain insignificant amounts of radioactive elements their further processing does not present environmental risks.

Another direction of red mud valorisation could be the recovery of $\mathrm{Fe}, \mathrm{Ti}, \mathrm{V}, \mathrm{Ga}, \mathrm{Sc}$, $\mathrm{Gd}$ by extraction. This method would be important especially in the case of $\mathrm{Ga}, \mathrm{Sc}$, $\mathrm{Gd}$, which are critical metals with specific properties and rarely encountered in natural ores.

\section{Acknowledgements}

Research work was completed under support of PN-II-PT-PCCA-2013-4-177 Ctr. 78/2014 and financial support of National Authority- UEFISCDI and MCI. The authors would like to thank a lot to Viorel Badilita for the professional support.

\section{References}

ASTM E1479 2016, Standard Practice for Describing and Specifying Inductively Coupled Plasma Atomic Emission Spectrometers.

Borra, Chenna Rao, Blanpain, B, Pontikes, Y, Binnemans, K \& Van Gerven, T 2016, 'Recovery of rare earths and other valuable metals from bauxite residue (red mud): a review', Journal of Sustainable Metallurgy vol. 2, no. 4, pp. 365-386.

O'Brien, J 2008, 'Potassium in Crop Nutrition', Plant Nutrition Newsletter, vol. 9, no.8, http:/weppi.gtk.fi, [17.05.2017].

Council Directive 91/689/EEC 1991, on hazardous waste, Official Journal L 377. 


\section{INTERNATIONAL SYMPOSIUM "THE ENVIRONMENT AND THE INDUSTRY", SIMI 2017, PROCEEDINGS BOOK}

Cengeloglu, Yunus, Esengul, Kir, Ersoz, Mustafa, Buyukerkek Tugba \& Gezgin, Sait 2003, Recovery and concentration of metals from red mud by Donnan dialysis`, Colloids and Surfaces A: Physicochemical and Engineering Aspects, vol. 223, no.1, pp. 95-101.

IEC 61010-2-061 2015, 'Safety requirements for electrical equipment for measurement, control and laboratory use - Part 2-061: Particular requirements for laboratory atomic spectrometers with thermal atomization and ionization ; International Electrochemical Commission

EN 55011 (Class B), European limits and methods of measurement of radio disturbance characteristics for scientific and medical equipment.

EN 61326-A1, Electrical equipment for measurement, control and laboratory use;

EN 61326-1(Class B), EMC requirements. - Part 1: General requirements.

Galateanu, Ioan 1976, Applied radiochemistry. Methods and problems, Academiei RSR Press, Bucharest, pp.105, in Romanian.

Hodgman, CD 1960, Handbook of Chemistry and Physics, edition 42, Chemical Rubber Publishing Co., Cleveland, Ohio, USA.

Paramguru, RK, Rath, PC \& Misra, VN 2004, 'Trends in red mud utilization-a review`, Mineral Processing and Extractive Metallurgy Review, vol. 26, no.1, pp.1-29.

Patent RO131328 (A2) 2016, 'Process for preparing ceramic foams based on red mud consist of gelling composition consisting of aqueous suspension of red mud, Derwent Innovation Index [17.05.2017].

Patterson, SH, Kurtz, HF, Olson, JC \& Neeley, CL 1986, 'World Bauxite Resources. Geology and Resources of Aluminium', U.S. Geological Survey Professional Paper 1076-B, U.S. Government Printing Office, Washington, pp. 18-22.

Sglavo,VM, Maurina, S, Conci, A, Salviati, A, Carturan, G \& Cocco G 2000, ‘Bauxite 'red mud'in the ceramic industry. Part 2: production of clay-based ceramics', Journal of the European Ceramic Society, vol. 20, no. 3 , pp. 245252.

Snars, K \& Gilkes, RJ 2009, 'Evaluation of bauxite residues (red muds) of different origins for environmental applications`, Applied Clay Science, vol. 46, no.1, pp. 13-20.

SR EN 60746-1 (CEI 60746-1) 2004, `Expression of performance of electrochemical analyzers - Part 1: General, Romanian Standardization Association.

SR EN 60746-2 (CEI 60746-2) 2004, ‘Expression of performance of electrochemical analyzers -Part 2: $\mathrm{pH}$ value`, Romanian Standardization Association.

SR 7184-13 2001, 'Soils. Determination of pH in water and saline suspensions (mass/volume) and in saturated paste', Romanian Standardization Association.

SR 9934-2 1998, 'Ash pyrite. Determination of moisture, loss of ignition and corrected loss of ignition, Romanian Standardization Association, in Romanian.

SR EN 12192-1 2003, 'Products and systems for the protection and repair of concrete structures - Granulometric analysis - Part 1: Test method for dry components of premixed mortar', Romanian Standardization Association.

SR EN 14242 2005, Aluminium and aluminium alloys - Chemical analysis Inductively coupled plasma optical emission spectral analysis`, Romanian Standardization Association. 
SR EN 24497 1994, 'Determination of granulation after stirring in dry condition', Romanian Standardization Association, in Romanian.

STAS 3223/2 1980, 'Determination of sodium. Drinking water, mineral water, surface water and wastewater', Romanian Standardization Association, in Romanian.

STAS 1269/17 1982, 'Copper, lead, zinc, bismuth, molybdenum, pyrite and complex sulphide ores and concentrates. Determination of calcium oxide and magnesium oxide content, Romanian Standardization Association, in Romanian.

STAS 1269/7 1983, 'Copper, lead, zinc, bismuth, molybdenum, pyrite and complex sulphide ores and concentrates. Determination of cadmium content', Romanian Standardization Association, in Romanian.

STAS 1269/3 1987, 'Ores and concentrates of copper, lead, zinc, bismuth, molybdenum, pyrite and complex sulphides. Determination of lead content, Romanian Standardization Association, in Romanian.

STAS 3223/1 1992, 'Determination content of potassium. Drinking water, mineral water, surface water and wastewater', Romanian Standardization Association, in Romanian].

UNSCEAR 2000, United Nations Scientific Committee on the Effects of Atomic Radiation, Report to the General Assembly with Scientific Annexes, vol. 1, pp. 87-105.

Yalçın, N \& Vahdettin S 2000, 'Utilization of bauxite waste in ceramic glazes`, Ceramics International, vol. 26, no.5, pp. 485-493.

Vitmeco Alum SA, www.alum.ro/article /, [17.05.2017]. 